\title{
The Usinsk Tuvans in the XXI Century
}

\author{
Victor P. Krivonogova and Yaroslavna S. Mikhailova ${ }^{\text {b* }}$ \\ ${ }^{a}$ Siberian Federal University \\ 79 Svobodny, Krasnoyarsk, 660041, Russia \\ ${ }^{b}$ Institute of Ethnology and Anthropology RAS \\ 32a Lininskii pr., Moscow, 119991, Russia
}

Received 01.12.2014, received in revised form 23.01.2015, accepted 03.02.2015

A small group of nomadic Tuvans have long lived in the south of Krasnoyarsk Krai, on the border with Tuva. They were considered non-residents and, thus, were not taken into account by statistics until Tuva became a part of the USSR. By the 1970-s they lived around Verkhneusinskoe and Nizhneusinskoe, Russian settlements, were engaged in cattle breeding. Their separate residence contributed to the preservation of the Tuvan language and culture. In 1990-s almost all the Tuvans moved to towns due to the cattle breeding reduction. Their contacts with the Russians also increased largely. The number of mixed marriages grew, and language and cultural assimilation started. Migrations resulted in the Tuvans' depopulation from 476 to 367 people. In the future a further growth of assimilation processes can be expected as the children predominantly speak Russian.

Keywords: the Usinsk Tuvans, modern ethnic processes, language assimilation, retreat from traditional practice, mixed marriages, miscegenation, processes of assimilation.

Research area: history.

In Russia the Tuvans live very compactly. Their large majority is concentrated within the boundaries of their republic. Those who are registered outside the republic, mainly in different cities of Russia, have left it temporarily (e.g., students). The number of those who have moved from the republic for permanent residence is extremely low. However, there is one place in Russia, where the Tuvans have been living for a long time, being its actual indigenous inhabitants. This is the territory to the north from Tuva's border, along the Usa River, in the south of Krasnoyarsk Krai. Being nomads in the past, local Tuvans wandered around both sides of the state border and, thus, were constantly on the Russian territory but in the status of the subjects of a foreign state. This ethno-territorial group of the Tuvans was named the Usinsk Tuvans after their habitat. Its population constantly changed in different periods due to a constant migration across the border in both directions. This group didn't attract the researchers' attention in the past and has never been an object of ethnographic studies. Only fragmentary data on their number and settlement in different periods are available (Datsyshen 2009, Istoriia Tuvy 2007, Potapov

(C) Siberian Federal University. All rights reserved

* Corresponding author E-mail address: Victor950@yandex.ru, Jasjamih@yandex.ru 
1969). The Tuvans of this territory were never in the focus of statistics until they became the USSR residents, the reason being their status of foreign people. Only later, in the 1950-s, the information about them appeared in the records of Verkhneusinsk village council. According to our estimates, the number of the Tuvans by 1972 was 476 people, or $15.6 \%$ of the total population of the village council (as per the data in the village council's register of farms). However, their majority did not live in the villages, among the Russians, but rather in isolation, on numerous cattle camps within 10-30 miles around the settlements. They lived by 2-4 houses near sheep yards, cowsheds, and other livestock barns. Only 108 Tuvans, that makes $22.7 \%$ of their total number, lived in the villages (which are two here, and namely Verkhneusinskoe, Nizhneusinskoe). The Tuvans' separate residence with the Russians helped to preserve the relative endogamy and the Tuvan language as a primary spoken and native one. In 1950-s there were only 2 mixed families whereas in 1972 their number was $8(8,7 \%$ of the total number of Tuvan families). Such families existed only among those few Tuvans, who moved to villages and lived in close neighbourhood with the Russians, the main population on this territory. Break-up of state farms and sharp reduction in cattle-breeding industry in the early 1990 -s resulted in the fact that a large number of the Tuvans who got unemployed moved to these two villages. This resulted in a new direction of ethnic processes and, thus, favoured a sharp increase in the interaction between the Tuvans and the Russians. Currently the total population of the two villages is 1990 persons (the year of 2012), of which the Tuvans are 367, or $18.4 \%$. 259 Tuvans live in Verkhneusinsk, 99 - in Nizhneusinsk, only 9 Tuvans reside outside the villages, and namely in Ust'-Teplaya camp. Economic problems and unemployment of the last twenty years caused the decrease in both general population and the
Tuvans, the main reason being their migration outside the territory.

In the summer of 2013 an ethnographic expedition was sent to the territory of Verkhneusinskoe village council with the aim to reveal contemporary ethnic processes peculiar to the local Tuvans. The methods of gathering information were the population's mass survey, based on ethnographic questionnaire and interviews with the informants, and statistic data studies. The questionnaire contained 47 questions on various spheres of life: material and spiritual culture, education, employment, language processes, etc. 279 respondents were interviewed, the data on children, who were younger than 16 , were given by parents. The task to interview not less than $3 / 4$ of the Tuvan population was achieved (76,0 \%).

A traditional activity of the local Tuvans as well as of the majority of the Tuvan population was cattle-breeding. However, the situation has drastically changed over the last two decades the Usinsk Tuvans' labour activity slightly differs from that of the local non-Tuvan population (Table 1).

According to the data, a very small part of the Tuvan population is engaged in cattle breeding, which was the main activity of the Tuvans not long ago. According to the pensioners, almost half of them were involved in cattle breeding in the past. The majority of those who are currently unemployed also did cattle breeding not long ago. The unemployment rate of the Usinsk Tuvans is extremely high. Some of them try to survive through personal farms, as well as hunting and gathering, all of them being traditional activities (Potapov 1969). Almost every family has a small plot of land (vegeTable garden) on which vegetables and berries are grown. We argue that the development of gardening can be logically explained by the influence of the Russian majority, neighbouring them. 
Table 1. The Usinsk Tuvinians' activities (survey data, \%)

\begin{tabular}{|c|c|c|c|c|c|}
\hline \multicolumn{7}{|c|}{ The Tuvans' activities } \\
\hline $\begin{array}{c}\text { general } \\
\text { workers-1 }\end{array}$ & $\begin{array}{c}\text { general } \\
\text { workers-2 }\end{array}$ & $\begin{array}{c}\text { qualified } \\
\text { workers }\end{array}$ & specialists & businessmen & the unemployed \\
\hline 5,4 & 17,0 & 5,4 & 8,2 & 1,4 & 62,6 \\
\hline
\end{tabular}

* General workers-1 are engaged in cattle and livestock breeding; general workers-2 are employed in other spheres but cattle breeding

Table 2. Need for national clothes (survey data, \%)

\begin{tabular}{|c|c|c|}
\hline \multicolumn{3}{|c|}{ Need for national clothes } \\
\hline regular & seldom & never \\
\hline $4,3 \%$ & $31,2 \%$ & $64,5 \%$ \\
\hline
\end{tabular}

Table 3. Need for national clothes with regard to different age groups (survey data, \%)

\begin{tabular}{|c|c|c|c|c|c|c|c|c|}
\hline & \multicolumn{9}{|c|}{ Age } \\
\cline { 2 - 10 } & under 10 & $10-19$ & $20-29$ & $30-39$ & $40-49$ & $50-59$ & $60-69$ & over 70 \\
\hline regular & 2,1 & & 2,1 & 2,2 & 6,8 & 4,7 & 11,1 & 50 \\
\hline seldom & 45,8 & 30,1 & 26,5 & 32,6 & 25 & 42,9 & 11,1 & \\
\hline never & 52,1 & 67,9 & 71,4 & 65,2 & 68,2 & 52,4 & 77,8 & 50 \\
\hline
\end{tabular}

Table 4. Need for national clothes with regard to males and females (survey data, \%)

\begin{tabular}{|c|c|c|}
\hline & males & females \\
\hline regular & 1,3 & 7,5 \\
\hline seldom & 29,4 & 33,9 \\
\hline never & 69,3 & 58,6 \\
\hline
\end{tabular}

One of the aspects of traditional material culture is national clothes. These are constantly worn by $4.3 \%$ of the respondents only (Table 2 ), who are mainly the elderly people over 70 (Table 3 ) and mostly women (Table 4 ). $31.2 \%$ of the Usinsk Tuvans wear national clothes occasionally, only on national holidays. The majority of the Usinsk Tuvans $(64,5 \%)$ never wear national clothes.

National Tuvan clothes are mainly bought in Tuva. They are often presented to the children as gifts. This largely determines the fact that children often wear national clothes.
It is the Usinsk Tuvans' cuisine that still fully preserves its national peculiarities. According to the informants, they often cook such dishes as tolgan, byshtak, hoitpak, etc. But their most popular dish is khan (black pudding). According to a survey, national dishes are cooked in $94 \%$ of families.

The Tuvan language is steadfastly kept in Tuva. But as the Usinsk Tuvans live in close neighbourhood with the Russians, their language situation is slightly different. It was successfully preserved till the 1990-s, that is till 
their settlement in Russian villages. However, there have been significant changes in language situation over the past 20 years. It began to retreat (Table 5).

$100 \%$ of the respondents over 70 consider the Tuvan language to be their native one (Table 6). The Table shows the process of reducing the share of those who consider the Tuvan language their native one from older to younger age groups. Thus, Russian distinctly prevails over Tuvan among children.

Indicators on primary spoken language (i.e. the language of regular communication) are of great importance to determine modern language processes. Russian obviously dominates here (Table 7).

According to the indicators on the degree of Tuvan and Russian language proficiency, only $68.1 \%$ of the Usinsk Tuvans are fluent in Tuvan (Table 8) with very significant differences as per age groups (Table 9). Whereas the age group over
70 is fluent in the Tuvan language, the rate for children is only $39 \%$.

$90 \%$ of the Usinsk Tuvans are fluent in Russian (Table 10), whereas only those who are over 70 have difficulties in it (up to $60 \%$ ).

The Tuvan language proficiency among the metis people (41.7\%) is lower than that among native Tuvans $(70.7 \%)$.

Until recently the Tuvan language has been taught at local school. However, the number of those who are willing to study it sharply reduced several years ago, and this subject was excluded from the curriculum. But still $75.8 \%$ of local Tuvans (over 7 years old) can write and read (other $7.9 \%$ can only read, and $16.3 \%$ cannot write, the latter being children of school age). As for the Russian language proficiency, almost everyone (except for a few old men) can write in Russian $(97,9 \%$ can read and write, $1.7 \%$ can only read, $0,4 \%$ have no knowledge of Russian).

Table 5. The Usinsk Tuvinians' native language (survey data, \%)

\begin{tabular}{|c|c|c|}
\hline \multicolumn{3}{|c|}{ Native language } \\
\hline Tuvan & Russian and Tuvan & Russian \\
\hline 60,2 & 22,6 & 17,2 \\
\hline
\end{tabular}

Table 6. The Usinsk Tuvinians' native language with regard to different age groups (survey data, \%)

\begin{tabular}{|c|c|c|c|c|c|c|c|c|}
\hline \multirow{2}{*}{$\begin{array}{c}\text { Native } \\
\text { language }\end{array}$} & \multicolumn{9}{|c|}{ Age } \\
\cline { 2 - 10 } & under 10 & $10-19$ & $20-29$ & $30-39$ & $40-49$ & $50-59$ & $60-69$ & over 70 \\
\hline Tuvan & 28,3 & 39,6 & 51 & 74 & 84 & 90,4 & 87,5 & 100 \\
\hline $\begin{array}{c}\text { Russian } \\
\text { and Tuvan }\end{array}$ & 30,3 & 34 & 30,6 & 13 & 16 & 9,6 & 12,5 & \\
\hline Russian & 41,4 & 26,4 & 18,4 & 13 & & & & \\
\hline
\end{tabular}

Table 7. The Usinsk Tuvinians' primary spoken language (survey data, \%)

\begin{tabular}{|c|c|c|}
\hline \multicolumn{3}{|c|}{ Primary spoken language } \\
\hline Tuvan & Russian and Tuvan & Russian \\
\hline 14,4 & 50,5 & 35,1 \\
\hline
\end{tabular}


Table 8 . The Tuvan language proficiency (survey data, \%)

\begin{tabular}{|c|c|c|c|c|}
\hline \multicolumn{5}{|c|}{ The Tuvan language proficiency } \\
\hline fluent & $\begin{array}{c}\text { with slight } \\
\text { difficulties }\end{array}$ & $\begin{array}{c}\text { with significant } \\
\text { difficulties }\end{array}$ & $\begin{array}{c}\text { understand the } \\
\text { language but cannot } \\
\text { speak it }\end{array}$ & $\begin{array}{c}\text { lack the knowledge } \\
\text { of the language }\end{array}$ \\
\hline 68,1 & 12,5 & 6,1 & 9,4 & 3,9 \\
\hline
\end{tabular}

Table 9. The Tuvan language proficiency with regard to age groups

\begin{tabular}{|l|c|c|c|c|c|c|c|c|}
\hline & \multicolumn{7}{|c|}{ Age } \\
\cline { 2 - 10 } & $\begin{array}{c}\text { under } \\
10\end{array}$ & $10-19$ & $20-29$ & $30-39$ & $40-49$ & $50-59$ & $60-69$ & over 70 \\
\hline fluent & 39,6 & 54,8 & 69,4 & 80,5 & 90,9 & 71,4 & 75 & 100 \\
\hline with slight difficulties & 14,5 & 16,9 & 10,2 & 10,8 & 6,8 & 19,1 & 25 & \\
\hline with significant difficulties & 10,5 & 7,6 & 8,2 & 2,2 & 2,3 & 9,5 & & \\
\hline $\begin{array}{l}\text { understand the language but } \\
\text { cannot speak it }\end{array}$ & 20,9 & 16,9 & 10,2 & 4,3 & & & & \\
\hline $\begin{array}{l}\text { lack the knowledge of the } \\
\text { language }\end{array}$ & 14,5 & 3,8 & 2 & 2,2 & & & & \\
\hline
\end{tabular}

Table 10. The Russian language proficiency (survey data, \%)

\begin{tabular}{|c|c|c|}
\hline \multicolumn{3}{|c|}{ The Russian language proficiency } \\
\hline fluent & with slight difficulties & with significant difficulties \\
\hline $90 \%$ & 7,9 & 2,1 \\
\hline
\end{tabular}

The data on the region's key languages provide the possibility to conclude that the process of language assimilation started at the beginning of the $1990-\mathrm{s}$, that is soon after the Tuvans' migration to villages. It was most vivid in the youngest age group, that is among those who were born in villages already. The situation in older age groups serves the evidence for the conclusion that there were practically no assimilation processes in language. It can be assumed that the assimilation tendencies in the Tuvan language will be growing in the nearest decades.

In recent decades the process of the Usinsk Tuvans' transition to Russian names is in progress. Nowadays the share of Tuvan names and patronymics is $13.4 \%$, the share of Russian names and patronymics is $42,2 \%$. The rest $44.4 \%$ have a combination of Russian and Tuvan names and patronymics (a typical case being a Russian name and a Tuvan patronymic; a rare case being a different combination).

The most common male names are Alexander, Andrey, Nikolay, Dmitry, Denis, Evgeny, and Maxim (there are more than four persons with these names). The same is true for one traditional Tuvan name, Ayas (4 persons). The most common female names are Marina, Vera, Lyudmila, Liubov', Elena, and Valentina. 
No traditional name is in the group of common names. However, it should be noted that there is much more variety in female traditional names than in male ones.

The assimilation processes in language caused the reduction in the Usinsk Tuvans' competence in those types of spiritual culture which are connected with the language. In particular, not all the respondents are familiar with the song genre in their native language (Table 11).

Every seventh respondent sings in Tuvan only, the rest sing either in Russian or in two languages (Table 12).

The children sing in Russian more often, which is in accord with the language competence (Table 13).

Young people, even if they sing in Tuvan, prefer modern pop songs, whereas elderly people prefer folk songs.

Table 11. Knowledge of Tuvan songs (survey data, \%)

\begin{tabular}{|c|c|c|}
\hline \multicolumn{3}{|c|}{ Knowledge of Tuvan songs } \\
\hline lack of knowledge & knowledge of 1-3 songs & knowledge of more than 3 songs \\
\hline 32,8 & 24,5 & 42,7 \\
\hline
\end{tabular}

Table 12. The language the Usinsk Tuvans sing songs in (survey data, \%)

\begin{tabular}{|c|c|c|c|}
\hline \multicolumn{4}{|c|}{ The language the Tuvan songs are sung } \\
\hline Tuvan & Russian and Tuvan & Russian & the songs are not sung \\
\hline 14,7 & 49,5 & 31,9 & 3,9 \\
\hline
\end{tabular}

Table 13. The language of songs with regard to different age groups (survey data, \%)

\begin{tabular}{|l|c|c|c|c|c|c|c|c|}
\hline \multirow{2}{*}{\multicolumn{1}{|c|}{ The language of songs }} & \multicolumn{9}{c|}{ Age } \\
\cline { 2 - 10 } & $7-9$ & $10-19$ & $20-29$ & $30-39$ & $40-49$ & $50-59$ & $60-69$ & over 70 \\
\hline Tuvan & 14,3 & 15,4 & 13,1 & 15,2 & 20,9 & 9,5 & & 20 \\
\hline Russian & 42,8 & 48,0 & 45,6 & 23,9 & 20,9 & 19,1 & 12,5 & \\
\hline $\begin{array}{l}\text { Tuvan } \\
\text { and Russian }\end{array}$ & 28,6 & 32,7 & 34,8 & 56,5 & 55,8 & 71,4 & 87,5 & 80 \\
\hline the songs are not sung & 14,3 & 3,9 & 6,5 & 4,4 & 2,4 & & & \\
\hline
\end{tabular}


Table 14. Knowledge of Tuvan tales (survey data, \%)

\begin{tabular}{|c|c|c|c|}
\hline \multicolumn{3}{|c|}{ Fairy tales } \\
\hline Fairy tales were not heard & $\begin{array}{c}\text { Fairy tales were heard } \\
\text { but cannot be told }\end{array}$ & $\begin{array}{c}\text { Knowledge } \\
\text { of 1-3 fairy tales }\end{array}$ & $\begin{array}{c}\text { Knowledge } \\
\text { of more than 3 fairy tales }\end{array}$ \\
\hline 20,5 & 30,8 & 10,7 & 38,0 \\
\hline
\end{tabular}

Table 15. Knowledge of Tuvan fairy tales with regard to different age groups (survey data, \%)

\begin{tabular}{|l|c|c|c|c|c|c|c|c|}
\hline \multirow{2}{*}{ Knowledge of Tuvan fairy tales } & \multicolumn{7}{|c|}{ Age } \\
\cline { 2 - 10 } & $7-9$ & $10-19$ & $20-29$ & $30-39$ & $40-49$ & $50-59$ & $60-69$ & over 70 \\
\hline fairy tales were not heard & 28,6 & 37,7 & 21,7 & 21,7 & 4,6 & 9,5 & 12,5 & \\
\hline $\begin{array}{l}\text { fairy tales were heard but cannot } \\
\text { be told }\end{array}$ & 57,1 & 35,8 & 41,3 & 28,3 & 32,6 & 9,5 & 12,5 & \\
\hline $1-3$ fairy tales & & 3,8 & 13,1 & 10,9 & 11,6 & 23,8 & 25 & \\
\hline more than 3 fairy tales & 14,3 & 22,7 & 23,9 & 39,1 & 51,2 & 57,2 & 50 & 100 \\
\hline
\end{tabular}

Table 16. Different age groups' familiarity with a traditional wedding ceremony (survey data, \%)

\begin{tabular}{|l|c|c|c|c|c|c|c|}
\hline \multirow{2}{*}{$\begin{array}{c}\text { Familiarity } \\
\text { with a wedding ceremony }\end{array}$} & \multicolumn{7}{c|}{ Age } \\
\cline { 2 - 9 } & $16-19$ & $20-29$ & $30-39$ & $40-49$ & $50-59$ & $60-69$ & over 70 \\
\hline familiar & 50 & 48,8 & 60,5 & 47,1 & 65 & 50 & 90 \\
\hline non-familiar & 50 & 51,2 & 39,5 & 52,9 & 35 & 50 & 10 \\
\hline
\end{tabular}

for a wedding); uktuuru (meeting a wedding procession); worshiping the spirits-masters of sacred places; use of a white khata as a sign of respect and reverence (Iusha 2008). According to the informants, there are traditional elements in the Usinsk Tuvans' wedding ceremonies (the use of white khata, for example).

According to the survey, a wedding ceremony or its elements are familiar to more than a half of the respondents $(57.4 \%)$.

Knowledge of wedding ceremony rules is influenced by several factors. The first one is age. The maximum rate is peculiar for the age group of people over 70 . The rate peculiar for other age groups is about $50 \%$ (Table 16 ).

The second influential factor is a spouse's nationality. Thus, in monoethnic Tuvan families $66,2 \%$ of the respondents are aware of a national wedding ceremony whereas in the families with a non-Tuvan spouse they are only $33.4 \%$.

The Usinsk Tuvans demonstrate better knowledge of a funeral ritual as well as its observance. A vast majority of the respondents $(89.4 \%)$ know the rules or elements of this rite.

The researchers note that the removal of a deceased after noon, availability of supporting things, abundant funeral offerings, memorial day celebration on the seventh and forty-ninth day (Kisel' 2009) are characteristic rituals for Tuvan obsequies in the republic nowadays. They are observed by the Usinsk territory group of the Tuvans. The informants and respondents often pointed to the tradition of making a pyre on the grave of a deceased. In Tuva they invite a shaman for this ritual which takes place on the third day (Ibid.). 
Taking the opinion of the majority of the residents into consideration, Verkhneusinsk Palace of culture (and its Nizhneusinsk branch) organizes traditional Tuvan holidays, such as Shagaa and Nadym. The holidays are widespread and celebrated by all the villagers regardless of their nationality. The survey has showed that the majority of the Usinsk Tuvans celebrate the holidays of various kinds: Tuvan, civil, and Orthodox ones (Table 17).

Adult respondents were asked to identify their religious affiliation. This resulted in the following responses: the unbelievers, Buddhism, Orthodox Christianity, Shamanism. Several respondents have declared themselves as Evangelic Christians. Dualistic religious self-identification is also observed: BuddhismShamanism, Orthodoxy-Buddhism, and Orthodoxy-Shamanism. There are even adherents to three religions - BuddhismOrthodoxy-Shamanism (Table 18).

More than a third of the Usinsk Tuvans $(35,9 \%)$ consider themselves to be unbelievers. A quarter of the respondents affiliate themselves with Buddhism. Buddhism in the form of Lamaism began to establish itself in Tuva at the close of the XVIII century, and its introduction started earlier, in the XIII - XIV centuries. Its mass distribution started after Tuva became dependent on China. Thus, Buddhist temples appeared, the clergy was formed, the population started to adhere to Buddhist rites (Potapov 1969). However, shamanism, the Tuvans' traditional belief, is still preserved. Whereas shamanism was chosen by $4.2 \%$ of the respondents only, it was mentioned in the combination with other religions by $23.9 \%$ of the respondents. Many researchers note that a peculiar feature of the Tuvans' world outlook is the combination of the elements of two religious systems (Vainshtein 1972). The data of the survey also prove the synthesis of the Tuvans' traditional beliefs and monotheistic religion. $14.1 \%$ of the respondents affiliated themselves with BuddhismShamanism combination of the religions. In Tuva the majority of the Tuvans identify themselves as half Buddhists and half shamanists (Mongush 2010).

Despite the predominance of the traditional religious organizations' influence (mainly Buddhist and shaman ones) Tuva faces the influence of non-traditional confessions of faith, a vigorous activity of Protestant religious

Table 17. Celebrated holidays (survey data, \%)

\begin{tabular}{|c|c|c|}
\hline \multicolumn{3}{|c|}{ Celebrated holidays } \\
\hline civil & Tuvan & Orthodox \\
\hline 97,5 & 85,0 & 75,0 \\
\hline
\end{tabular}

Table 18. The Usinsk Tuvans' religious affiliation (survey dada, \%)

\begin{tabular}{|c|c|c|c|c|c|c|c|c|}
\hline \multicolumn{9}{|c|}{ Religious affiliation } \\
\hline 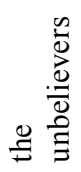 & 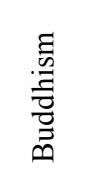 & 希 & 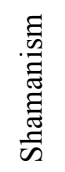 & 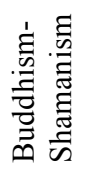 & 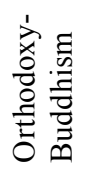 & 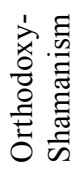 & 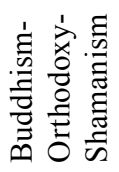 & 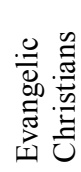 \\
\hline 35,9 & 25,5 & 9,4 & 4,2 & 14,1 & 1,5 & 1,5 & 4,1 & 3,8 \\
\hline
\end{tabular}


Table 19. The Usinsk Tuvans' religious affiliation with regard to different age groups (survey data, \%)

\begin{tabular}{|l|c|c|c|c|c|c|c|}
\hline \multirow{2}{*}{\multicolumn{1}{c|}{ Religious affiliation }} & \multicolumn{7}{c|}{ Age } \\
\cline { 2 - 8 } & $16-19$ & $20-29$ & $30-39$ & $40-49$ & $50-59$ & $60-69$ & over 70 \\
\hline the unbelievers & 53,9 & 59,5 & 23,2 & 18,6 & 35 & 50 & 40 \\
\hline Buddhism & 30,9 & 35,1 & 25,6 & 34,9 & & & 20 \\
\hline Orthodoxy & 3,8 & 5,4 & 16,3 & 13,9 & 5 & & 10 \\
\hline Shamanism & 3,8 & 2,7 & 2,3 & 7 & 5 & 12,5 & \\
\hline Buddhism- Shamanism & 3,8 & 10,8 & 18,6 & 9,3 & 40 & 12,5 & 10 \\
\hline Orthodoxy- Buddhism & & & 2,3 & 2,3 & & 12,5 & \\
\hline Orthodoxy- Shamanism & & & 2,3 & & 5 & & 10 \\
\hline Orthodoxy- Buddhism- Shamanism & & & 2,3 & 9,3 & 5 & 12,5 & 10 \\
\hline Evangelic Christians & & & 7 & 4,6 & 5 & & \\
\hline
\end{tabular}

organizations having their branches not only in large cities but also in remote kozhuuns (districts) (Ibid.). The Usinsk Tuvans also faced these. According to the survey, $3.8 \%$ of the Usinsk Tuvans affiliated themselves as Evangelical Christians. Some of the respondents have evangelistic Bible translated into the Tuvan language. According to the informants, Evangelical Christians here are not only the Tuvans, but some Russians as well.

Close neighbourhood and intensive contacts with the Russians led to the dissemination of Orthodoxy among the Usinsk Tuvans (16,5\%), often in combination with other religions (7,1\%). The respondents affiliating themselves with three religions (Buddhism-Orthodoxy-Shamanism) rate to $4.1 \%$.

Mostly the youth and elderly people belong to the unbelievers (Table 19). Most adherents to the religious world outlook are among the group of the middle aged (30-50 years old). This age group is mostly Buddhists and Orthodox. Adherents of shamanism are mostly among those who are over 50 .

Inter-ethnic marriages are one of the forms of inter-ethnic communication. As it has been previously mentioned, according to the register of farms, in the early 1970-s the share of mixed families in the villages with a minority of the
Tuvans (27.6 \%) was $8.7 \%$ whereas there were no such families outside the villages. Now, according to our sample data, the total share of mixed families in all the settlements is $31.7 \%$. Two thirds of all mixed families were families mixed with the Russians, one third of them was families mixed with other nationalities (we registered single marriages with the Chuvash and Khakass people, Germans, Ukrainians, etc.). There are no inter-ethnic marriages only among the older generation (those who are over 70). The share of inter-ethnic marriages of other age groups is from 11 to $46 \%$.

Women join inter-ethnic marriages more often that men (Table 20). According to our sample group, $30.1 \%$ of Tuvan women are in mixed marriages while the share of men in them is only $12.7 \%$.

A considerable number of mixed marriages lead to the birth of the metis people. They are $10.7 \%$ of the respondents (Table 21).

There would be much more metis people among the Usinsk Tuvans if they affiliated themselves with this nationality. But it turned out that children in mixed families are often assigned by the parents to the other spouse's nationality. This explains the fact why they were not among the respondents, considering themselves to be the 
Russians. This orientation of the metis people along with the young people's migration to cities is one of the reasons of the Usinsk Tuvans' depopulation.

Most Usinsk Tuvans are quite tolerant towards various kinds of contacts with the Russian majority. For example, their response to the question about their attitude to inter-ethnic marriages was that the other spouse's nationality did not matter (Table 22).

As the Russians constitute the majority on this territory, it is the Russians whom the Usinsk Tuvans contact at different levels: at work, at home, etc. That is why the survey contains the question "How would you characterize your relationships with the Russian population?". The vast majority's reply was "normal" (Table 23).

The Usinsk Tuvans' opinion on the future of their territorial group is very important. The respondents were asked the following question "Do you think the Usinsk Tuvans will survive with their ethnic features in the future?". Almost half of the respondents gave an optimistic reply, $15.5 \%$ believe that they will soon disappear as they will get assimilated, leave their place, and more than one third failed to give an unambiguous answer (Table 24).

Table 20. The share of people in mixed marriages (survey, \%)

\begin{tabular}{|c|c|c|}
\hline Nationality of a spouse & Males & Females \\
\hline The Tuvinians & $87,3 \%$ & $69,9 \%$ \\
\hline The Russians & $8,5 \%$ & $3,7 \%$ \\
\hline The Chuvash people & & $1,9 \%$ \\
\hline The Kirghiz & & $1,9 \%$ \\
\hline The Avars & & $1,9 \%$ \\
\hline The Ukrainians & & \\
\hline The Khakass people & $2,1 \%$ & \\
\hline The Germans & $2,1 \%$ & \\
\hline
\end{tabular}

Table 21. The Usinsk Tuvans' ethnic composition as per genealogy data (survey data, \%)

\begin{tabular}{|c|c|c|c|c|c|}
\hline \multicolumn{7}{|c|}{ The Tuvinians' ethnic composition } \\
\hline $\begin{array}{c}\text { Having only } \\
\text { backgan ethnic }\end{array}$ & $\begin{array}{c}\text { Tuvan and } \\
\text { Russian metis } \\
\text { people }\end{array}$ & $\begin{array}{c}\text { Tuvan and } \\
\text { Chuvash metis } \\
\text { people }\end{array}$ & $\begin{array}{c}\text { Tuvan and } \\
\text { Khakass metis } \\
\text { people }\end{array}$ & $\begin{array}{c}\text { Tuvan and } \\
\text { Azerbaijan metis } \\
\text { people }\end{array}$ & $\begin{array}{c}\text { Tuvan and Yakut } \\
\text { metis people }\end{array}$ \\
\hline 89,3 & 8,7 & 1,1 & 0,3 & 0,3 & 0,3 \\
\hline
\end{tabular}

Table 22. The Usinsk Tuvans' attitude towards interethnic marriages (survey data, \%)

\begin{tabular}{|c|c|c|c|}
\hline \multicolumn{3}{|c|}{ Attitude towards interethnic marriages } \\
\hline Their attitude is positive & $\begin{array}{c}\text { They consider a spouse's } \\
\text { nationality to be of no } \\
\text { importance }\end{array}$ & $\begin{array}{c}\text { They prefer monoethnic } \\
\text { marriages }\end{array}$ & $\begin{array}{c}\text { They found difficulty } \\
\text { in replying }\end{array}$ \\
\hline 8,6 & 56,8 & 18,7 & 15,9 \\
\hline
\end{tabular}


Table 23. The Usinsk Tuvans' view on their relations with the Russians (survey data, \%)

\begin{tabular}{|c|c|c|}
\hline \multicolumn{3}{|c|}{ The view on the relations with the Russians } \\
\hline "normal" & "one can never tell" & "so-so" \\
\hline 92 & 5,7 & 2,3 \\
\hline
\end{tabular}

Table 24. The Usinsk Tuvans' opinion on the prospect of preserving their territorial group in the future (survey data, \%)

\begin{tabular}{|c|c|c|}
\hline \multicolumn{3}{|c|}{ Will there be the Usinsk Tuvans in the future? } \\
\hline Yes & No & "It is difficult to answer" \\
\hline $48,4 \%$ & $15,5 \%$ & $36,1 \%$ \\
\hline
\end{tabular}

Hopefully this unique group with its peculiar cultural and ethnic features will survive, taking only the best of Tuvan and Russian cultures. However, many facts indicate that the processes of the Tuvans' assimilation have been actively developing after the Tuvans' mass migration from their camps to villages twenty years ago.

\section{References}

1. Datsyshen V.G. Tuvinskoe naselenie Usinskogo pogranichnogo okruga Eniseiskoi gubernii. Iz istorii russko-tuvinskikh otnoshenii [The Tuvinians of the Usinsk border district of Eniseisk province]. Novye issledovaniia Tuvy, 2009, 3, available at: http://www.tuva.asia/journal/ issue_3/465-dasishen.html.

2. Istoriia Tuvy: Tom II [History of Tuva. Vol. II] / Ed. by V.A. Lamin. Novosibirsk, 2007.

3. Iusha Zh. M. Svadebnaia obriadnost' tuvintsev: Traditsii i innovatsii [The Tuvinians' wedding ceremony: Traditions and innovations]. Traditsii $i$ innovatsii $v$ sovremennom fol'klore narodov Sibiri. Novosibirsk, 2008.

4. Kisel' V.A. Poezdka za krasnoi sol'iu. Pogrebal'nye obriady Tuvy. XVIII - nachalo XXI v. [Journey for ferrycianide. Funeral rites in Tuva. The XVIII-th century - turn of the XIX-th century]. St.-Petersburg, 2009.

5. Mongush M.V. Odin narod: tri sud'by. Tuvintsy Rossii, Mongolii i Kitaia v sravnitel'nom kontekste [One people: three fortunes. Russian, Mongolian and Chinese Tuvinians in the comparative context]. Osaka, Natsional'nyi muzei etnologii, 2010.

6. Potapov L.P. Ocherki narodnogo byta tuvintsev [Essays on the Tuvinians' folk life]. Moscow, 1969.

7. Vainshtein S.I. Istoricheskaia etnografiia tuvintsev. Problemy kochevogo hoziaistva [Historical ethnography of the Tuvinians. Problems of nomadic economy]. Moscow, 1972. 


\title{
Усинские тувинцы в XXI веке
}

\author{
В.П. Кривоногов ${ }^{\mathbf{a}}$, Я.С. Михайлова ${ }^{6}$ \\ ${ }^{a}$ Сибирский федеральный университет \\ Россия 660041, Красноярск, пр. Свободный, 79 \\ ${ }^{6}$ Институт археологии и этнографии СО РАН
}

Россия, 630090, Новосибирск, пр. Ак. Лаврентьева, 17

Издавна на юге Красноярского края, на границе с Тувой, проживала небольшая группа кочевых тувиниев. До вхождения Тувы в состав СССР они считались иностраниами и не учитывались статистикой. К 1970-м годам тувинцы проживали вокруг русских поселков Верхнеусинское и Нижнеусинское, занимаясь скотоводством. Раздельное проживание способствовало сохранению тувинского языка и культуры. В 1990-е годы в связи с сокращением скотоводства почти все тувинцы переселились в поселки и контакты с русскими резко активизировались. Возросло числоначионально-смешанных браков, началасьязыковая и культурная ассимиляция. Миграции привели к сокращению численности тувинцев с 476 до 367 человек. В перспективе можно ожидать дальнейшего развития ассимиляционных процессов, так как в детской возрастной группе уже преобладает русский язык.

Ключевые слова: усинские тувинцы, современные этнические процессы, языковая ассимиляция, отход от традиционных занятий, национально-смешанные браки, метисация, ассимиляиионные процессы.

Научная спеичильность: 07.00.00 - исторические науки. 